\title{
Shopping Script and Marketing Research
}

\author{
Manlio Del Giudice*
}

\begin{abstract}
Today's global markets have brought a new definition of the concept of loyalty. If a customer enjoys a continuous purchasing experience with a single supplier, he will develop a behavioural pattern, known as a 'shopping script', which may reduce his cognitive effort and optimise purchasing times.

The possession of the script and the customer satisfaction inherent in its use, shape the switching costs which act as change resistance factors from the customer point of view.

The script belongs to the wider family of cognitive patterns. It represents a pattern that contains knowledge of the temporal sequence of an event and it is used by the individual to understand events and to reduce the cognitive effort.
\end{abstract}

Keywords: Marketing Research; Market Research; Shopping Scripts; Cognitive Processes; Marketing; Global Markets

\section{Shopping Scripts in Marketing Research}

The question of customer loyalty has been analysed in depth in academic and managerial literature in recent years ${ }^{1}$. In situations of over-supply ${ }^{2}$, the evolution of forms of competition, the gradual saturation of many markets, and the structural changes of the trading processes induced by the emergence of the digital economy, have stepped up interest in the links between demand and supply, as a direct consequence of the growing technological, competitive and relational complexity that permeates the markets ${ }^{3}$. Moreover, the awareness that the 'Customer Theory' and the behavioural models of demand did not suitably analyse the phenomena triggered by the purchasing decision and the evaluation of repurchasing options, has been highlighted by numerous scholars ${ }^{4}$. Only recently the study of demand behaviour has revealed that it is essential to extend research into product-customer interrelations after purchasing, in order to generate new understanding of a key aspect such as the customer loyalty. Today's global markets have brought a new definition of the concept of loyalty and related issues ${ }^{5}$. The increase in cognitive power and greater eclecticism on the part of the customer, a greater propensity for

*Lecturer in Management, Second University of Naples (manlio.delgiudice@unina2.it)

Del Giudice Manlio, Shopping Script and Marketing Research, Symphonya. Emerging Issues in Management (symphonya.unimib.it), n. 2, 2003, pp. 58-72

http://dx.doi.org/10.4468/2003.2.06delgiudice 
'infidelity' on his part, the spread of individual consumption models, the gradual increase in consumers' expectations, and the growing and changing link between supply and demand have outlined a dynamic relationship between the corporate system and the customer ${ }^{6}$.

The basic hypothesis of this study is thus linked to the concept of the shopping script: if a customer enjoys a continuous purchasing experience with a single supplier, he will develop a behavioural pattern, known as a 'script', which may reduce his cognitive effort and optimise purchasing times. The hypothesis of the research is that once he masters this shopping script, the customer will be more reluctant to abandon his customary supplier. In other words, the possession of the script and the customer satisfaction inherent in its use, shape the switching costs which act as change resistance factors from the customer point of view.

In cognitive psychology, a script is a memory structure that represents stereotypical knowledge related to a sequence of actions. Scripts originate from a social phenomenon, which is exploited in turn by the mind to simplify reasoning in all the situations that are part of it. The script belongs to the wider family of cognitive patterns. It represents a pattern that contains knowledge of the temporal sequence of an event and it is used by the individual to understand events and to reduce the cognitive effort ${ }^{7}$. The progress achieved over the years by cognitive psychology has aroused growing interest among various scholars of management, who are verifying whether the concept of the script is applicable to their research ${ }^{8}$. Over the years, a branch of managerial literature has concentrated in particular on the seller's behaviour ${ }^{9}$. The application of the script to the relationship in question stems from the fundamental consideration that during their experience sellers develop an understanding of a certain number of procedures that are suitable for every sales situation ${ }^{10}$. To be effective, sellers need a type of processed knowledge that allows them to identify the type of sale, to classify the type of customer and to select the most appropriate selling and retention strategies. With experience, these strategies can be transformed into a series of behavioural scripts. In an absolutely specular manner, another branch of literature has analysed the purchaser's behaviour, using the script concept and demonstrating that during their interaction with the selling structure, purchasers develop a number of stereotyped actions, in an orderly sequence. According to these authors, scripts guide the individual's purchasing considerations, allowing him to develop a number of expectations and to behave in an appropriate manner during his shopping expeditions. After the first articles by Leigh and Rethans (1983), Stolman et al. (1989) confirmed the sequential, homogeneous structure of the script, focusing on the habits of customers who frequented several points of sales (therefore typically disloyal): the results of the study confirmed and emphasised the role played by the context in a sort of enactment of the script ${ }^{11}$. Moreover, the concept of 'expectation' at the basis of the performance of a purchasing script also underpins the studies by Oliver (1980) and by Tse and Wilson (1988) into customer satisfaction, which adopted the confirmation/disconfirmation paradigm and measured the gap between expectations and end result. Similarly, and this may be considered an important aspect of this study, Alford (1998) demonstrates not only that a negative deviance influence satisfaction and the intention to repurchase (automatically implying resistance to change in the case of the satisfactory confirmation of the script), but also that even a positive deviance from the script, seen as a pleasant but unexpected action, has a positive effect on the general level of satisfaction and on the intention 
to repurchase. From a managerial perspective, this research allows us to reflect on the concept of customer satisfaction in terms of consistency between the script learned and expected and the company's products, where both the process and results are concerned. The assumption behind this study is very similar to the hypotheses developed by Hubbert et al. in 1995, regarding the consistency between the script learned by the customer and the script transferred by the supplier company. The interaction between players during the experience may verify the subsistence of idiosyncratic relations between them. In the case of consistency between the script induced and the script learned, authors identify the possible satisfaction and presume resistance to change on the part of the customer, albeit without verifying it.

\section{Shopping Scripts and Resistance to Change}

Research into cognitive patterns has revealed that the benefits of using a pattern are related to the reduced cognitive effort necessary to execute the activities contained in the script, and to the ease of processing new information. These benefits, together with the individual's tendency to maintain his convictions unchanged, consolidating the cognitive maps in his own mind set, create resistance to change. For the individual, changing patterns is cognitively expensive because it takes time, reprocessing information and subverting what has already been built. And if the acquired pattern incorporates the satisfaction of the customer who enjoys a pleasant, fruitful and fast shopping expedition, thanks to the script, then the reluctance to change will be even more marked. The managerial consequence regards the possibility of fomenting a customer's loyalty on the basis of the psychological and cognitive costs necessary to modify the shopping script previously learned, where this script is likely to act as a source of customer satisfaction. In the early Eighties, Gronröos (1983) first mentioned 'interactive' marketing, stating that the quality perceived by the customer and his repurchasing behaviour were closely dependant on the (perceived) quality of the interaction. Starting from the empirical evidence noted in business-to-business markets, some authors from Northern Europe have begun to investigate the characteristics of the trading processes that are repeated in time and based on social, dyadic and network relations, fostering behaviour based on cooperation and on a true partnership between sellers and buyers. Moreover, in management studies, resistance to change is taken to explain so-called "switching costs". In the study of the individual's decision-making processes, the theory of limited rationality initially provided a fundamental contribution to understanding of how individuals manage these processes, starting from the studies by Simon $(1977)^{12}$. In the presence of cognitive constraints and, more generally, of the phenomenon of limited rationality, individuals activate certain processes to simplify decision-making process ${ }^{13}$. The theory of limited rationality, however, has not been used exclusively to understand the individual's decision-making process and the presence of switching costs. For example, Coase (1937) states that the space for entrepreneurial development emerges from the existence of limits to the capacity to process information on the part of players involved in the decision-making process and therefore, generally, to the presence of costs related to collecting information, to decision making, to negotiating and to control activity. Williamson (1975) developed Coase's theories, 
focusing his research on the transaction of goods and services between companies, and noting that costs were associated with every transaction within the market ${ }^{14}$, and the entity of these costs was influenced by three conditions: the specificity, the uncertainty and the frequency of the transaction. Barney \& Ouchi (1984) extended and generalised Williamson's distinction, recognising other mechanisms to manage these transactions. In line with Williamson's theory, the conditions of the transactions (specificity, uncertainty and frequency) influence a customer's choice of a continuative, privileged relationship with a single supplier. For example, where specificity is concerned, we should think of the mutual knowledge that can develop between a customer and a supplier who cooperate continually (this is even more the case with B2B): knowledge of each other's languages, of the purchasing preferences, of the administrative procedures, of the quality of results, etc. As a consequence, in the presence of such complex information, the cost of establishing new transactions in the place of those already known could prove too high, suggesting an investment in a collaborative relationship with the current supplier (which is even more true if the collaborative relationship identifies, as its primary goal, the customer satisfaction). The customer's resistance to change may therefore be expressed through the concept of switching costs. In economics, Klemperer (1987a) postulated the existence of three types of switching costs: transaction costs which arise when a relationship is established or interrupted; learning costs (costs that the individual or the company must meet to learn to use a new product or service) and contract costs (generated primarily by the company with the twofold goal of rewarding habitual customers and making new customers loyal). Starting from the Nineties, switching costs started to be more closely linked to retention: for example, Guiltinan (1989) maintained that switching costs constituted a mechanism that could be used to develop repetitive relations with the customer. Dick \& Basu (1994) also maintained that switching costs could translate into the choice settings of the end consumer. The customer's resistance to change the suppliers is supported in literature by analysis of the various types of switching $\operatorname{costs}^{15}$ : continuity costs, learning costs and sunk costs. In particular, continuity costs are identified on the basis of the consideration that the specific skills and capabilities acquired by the supplier to satisfy the customer's expectations in full could constitute a measure of dissuasion to changing supplier ${ }^{16}$ (recent American literature includes so-called lost performance costs in this category) ${ }^{17}$. These costs also include the risk that the customer perceives in replacing a known performance with another, which is unlikely to be on the same level as the former, and which can have serious consequences if it fails (Jones et al., 2002), classifying the socalled uncertainty costs in this group ${ }^{18}$. A customer may therefore familiarise with the procedures and standards of a supplier up to the point of refusing to consider the possibility of changing to another supplier, out of concern that the new one may be very different from the one he is accustomed to. In recent managerial literature, Jones et al. (2002, p. 443) proposed breaking learning costs down into evaluation and pre-switching costs ${ }^{19}$, cognitive or behavioural post-switching costs ${ }^{20}$ and finally set-up $\operatorname{costs}^{21}$. Economic literature repeatedly refers to the fact that a customer who decides to change his habitual supplier needs to accumulate a series of "competences of the novice user" 22 . These competences or "customer knowhow' represent his understanding of his own role in the context of the way the trading relationship is conducted, and the concept of shopping script describes them effectively ${ }^{23}$. In a broader interpretation, the shopping script defines a 
stereotypical relationship which keeps the consumer's cognitive efforts to a minimum and simplifies shopping expeditions, automatically creating resistance to change, when it includes the various classes of switching costs. Changing suppliers after having learned a consolidated behavioural script demands an investment in terms of time and effort, to learn a new process and define a new script. In this regard Heskett, Sasser \& Hart (1990, p. 44) justify the customer's tendency to continue his relationship with his habitual supplier by a 'natural aversion to learning new routines associated to the service'. And finally, the cost of amortisation or 'psychological involvement' (sunk costs) can be linked to expenses that the customer has met in the past and which, although with more incidence on the current state of affairs, continue to be psychologically significant.

\section{Global Markets, Scripts and Cognitive Processes of the Customer- Company}

Maintaining relations with a single supplier makes it possible, on one hand, to eliminate the cost of starting up new transactions and, on the other, to benefit from the advantages deriving from the longevity of the relationship, such as the creation of a common language between supplier and customer, the reduction of uncertainty regarding the end result of the transaction, and the serial equality of the relationship. If we transfer this purchasing experience to the online customercompany, the protagonist of this study, some interesting conclusions emerge ${ }^{24}$. The empirical check that follows concentrates on the role of the script for the customercompany who is a player in a global market: the digital economy. It therefore seems plausible to imagine that, in a similar context, if the customer repeats an operation (in the case in question, exploring specific search tools or simplified routes in a website to complete the shopping expedition) and acquires a behavioural script (which explains why he knows the particular type of process that leads to a purchase), when he repurchases, he will recall the known script and repeat the purchase from the same company, as a rule using the repetition of a familiar, satisfying and known situation to make his decision ${ }^{25}$. In this context, the following study does not only state that the customer-company should limit his purchasing choice on the basis of the pure and simple availability of the script in his memory, as some cognitive psychological literature has stated ${ }^{26}$. It goes further, trying to demonstrate, supported by empirical analysis, that in the competitive dynamism of the global markets, a script that is based on the intimate satisfaction of the individual who has experienced it, will make it more probable that the script will be re-used, because the cost of losing the script would be too high for the individual's perception ${ }^{27}$. It is now necessary to demonstrate the cognitive processes latent in the formation of the customer-company's concept of a script. The literature assigns particular importance to processes that determine: a) the customer-company's tendency to reveal a certain cognitive inertia, or to look for confirmation of what has already been experienced (selective processes) ${ }^{28}$; b) the production of information suitable to orientate purchasing/consumption decisions and use experience (associative processes); c) the organisation of this information to assess, ex ante and ex post, the value and usefulness generated by the product/service selected (evaluation processes) ${ }^{29}$. The aim of selective processes is to preserve the constructs of pre-existing knowledge and, in particular, the 
customer-company's attitudes to the relationship. They can be broken down into three fundamental components: a) the cognitive component, concerning the knowledge and convictions of the customer-company; b) the affective component, related to the emotional and value sphere (accentuated in $\mathrm{B} 2 \mathrm{C}$, but rather limited in this case, as far as the customers belong to the $\mathrm{B} 2 \mathrm{~B}$ sector); c) the pragmatic component, which translates into a definite behavioural orientation (particularly accentuated, in view of the characteristics of the decision-making process and of the rationality of the customer-company's script). Each component, in turn, is characterised by a sum of values deriving from the customer's deep-rooted convictions, whose intensity is an indication of the resistance to change of the various components. The stability of a given attitude therefore depends on the existence of a dual consonance: at a global level, between the cognitive, affective and pragmatic components; at a disaggregated level, between the values connected to each component. The selective processes aim to avoid situations of unbalance due to dissonance between the cognitive, affective and pragmatic components that define the structure of the attitudes. They are founded on the activation of mechanisms of selective exposition and attention to the congruent data with the expectations deriving from the knowledge held and with previous choices; to the data congruent with the expectations deriving from the knowledge held and the progressive choices; the selective understanding of the data, i.e. the attribution to the data of a consistent significance regarding existing cognitive patterns; and finally, the selective retention of the data able to produce information aligned to the consolidated system of values, convictions and attitudes. From the company's perspective, the understanding of the mechanisms described proves to be fundamental for the purposes of the creation and development of the customer's loyalty. And since the loyalty is a trust-driven resource, it is consequentely fed by information that can corroborate the cognitive patterns produced by the customer ${ }^{30}$. Moreover, the capacity of the customer-company to define a shopping script within its cognitive system is likely to be also influenced by the supplier's ability to outline the boundaries of this script, avoiding the creation of dissonant information, induced by shopping experiences that do not meet expectations ${ }^{31}$. Associative processes play a fundamental role in the creation of a shopping script by the customer: during the purchasing process, the customer-company defines a network of mental associations between the characteristics of the products and services and its own sphere of values. However, this brings the contents of these associations to three levels of abstraction, each one leading to the next, represented: a) by the attributes inherent in the cognitive script defined; b) by the benefits that can derive from the latter; c) by the individual values of the customer-company. Resistance to change therefore springs from the association of the attributes and benefits that can derive from learning a behavioural and cognitive script and the customer's scale of values (in B2B, values will focus on minimising purchasing time, on speeding up shopping expeditions, on the immediate recognition of the customer and the benefits related to its status, etc.). And finally, through its evaluation processes, the customer finalises its purchasing process, defines a shopping script and verifies the validity of the choices made ${ }^{32}$. The main cognitive constructs on which the evaluation and elaboration processes of the shopping script are based are subjective convictions and objective criteria of choice (provided by the customer service facilities offered by the supplier). Their interaction triggers the formation of defined pre-purchasing attitudes, which in turn translate into specific expectations 
of the goods and services compared and into a purchasing decision. The information that emerges from the use of the option selected retroacts on the convictions and criteria, confirming or negating these knowledge structures (confirmation/disconfirmation paradigm). This retroaction produces a postpurchasing attitude; the perceived level of satisfaction, any resistance to change and the desire to use the shopping script again depend on the comparison between this attitude and expectations, because it brings satisfactory results, and therefore, eventually, foments customer loyalty. The associations that the customer uses in order to differentiate between existing options and the choices made to define the shopping script are based on definite tangible and intangible attributes, whose correlation with the benefits hoped for and the individual value system directs the evaluation processes ${ }^{33}$. Separate analysis of the numerous evaluation parameters does not allow the company to determine the effects that an increase (or reduction) in the intensity of a certain attribute can exert on the perceived value of the shopping script, and therefore on the cognitive dimension of loyalty. The preferences produced by the final definition of the script, supported by confirmation of the expectations matured during purchasing, therefore show substantial stability, further enhanced by the weight of the satisfaction innate in the script itself. Given the importance attributed to the shopping script by the customer, on a managerial and not only a psychological level, it is still extremely probable that phenomena of cognitive dissonance will emerge. These must find a positive solution if loyalty is to develop towards a habitual supplier, preventing switching behaviour. The customer's choices thus depend on convictions matured actively in the experience of the purchasing script. In similar circumstances, purchasing problems induce the customer to adopt habitual behaviour which can be attributed to the desire of simplifying the purchasing process, saving time and developing the imperative of satisfaction in the script.

\section{Empirical Verification in a Global Context}

The empirical analysis of the following research was performed on a cluster of 280 companies in the hi-tech sector ${ }^{34}$. The analysis was prompted by the selection of scales/items through a pilot test conducted by in-depth interview ${ }^{35}$, sustained by bibliographical recognition ${ }^{36}$. At this stage the work consisted in a series of in-depth interviews to the top managers of 20 Italian companies operating in the B2B IT sector (4 as suppliers, 16 as customers). The analysis of the interviews made it possible to conceptualise the goal of the research and its reference variables: firstly, it was apparent that the shopping script evolved from knowledge of the purchasing environment (in this case, the website and the elements of its customer service); secondly, the possession of the shopping script automatically triggered a physiological reluctance of the customer to change suppliers. For the purposes of the present research, a possible consequence of the heightened loyalty induced by resistance to change was also tested: the customer's spontaneous willingness to pay a premium price to conserve the privileges guaranteed by the shopping script developed (this construct is commonly indicated in the managerial literature as the 'willingness to pay more'). The research hypotheses can therefore be summarised in the following statements: 
H1: Knowledge of the shopping script has a positive impact on the customer's resistance to change;

H2: Knowledge of the shopping script has a positive impact on the customer's willingness to pay more.

The in-depth interviews conducted made it possible to generate an initial pool of scales and items related to the 'costs of change' and to the 'knowledge of the shopping script' constructs ${ }^{37}$. With the help of three lecturers in the Marketing area of the Grenoble Ecole de Management, and following the empirical evidence in the literature, the items were revised, eliminating those deemed not significant. The final end result was an online questionnaire, divided into three sections: a) a first section related to the change resistance factors in a digital environment (classification of switching costs), composed of 30 items; b) a second section related to the concept of knowledge of the shopping script, composed of 8 items; c) a third section related to the concept of willingness to pay more, composed of 4 items. Sections a) and b) were used in the first stage of this study (development of explorative analysis). Section c) was added in the second stage (development of confirmatory model). The first stage of this study consists in the development of a factor, exploratory analysis, after the data have been collected with the questionnaire prepared ${ }^{38}$. The sample was created by using the customer database of the leading supplier of B2B IT products in Italy, Esprinet SpA (www.esprinet.com) ${ }^{39}$. A total of 100 customer companies was selected from the database, with inhomogeneous structural characteristics (in order to guarantee the representative nature of the sample), but continuous online purchasing (to guarantee the homogeneity of the purchasing perceptions). The interviewees, who took part in the research voluntarily and unpaid, were invited to respond online using an ASP questionnaire that was resident on the web, anchored to an SQL Server database. The answering rate was consistent (67\%), underlining the interest of the top managers of the companies interviewed, who were sent the link to the questionnaire directly and invited to take part. The first stage produced 67 completed questionnaires, from as many companies selling IT products (hardware, software) at a B2B level. Exploratory factor analysis was conducted to determine which latent variables could be significant to process the model and to test the hypotheses. Analysis of Cronbach's Alpha revealed generally satisfactory levels of the internal consistence of the selected items $(0.83<\alpha<0.95)$. The items were subsequently refined and selected, and the latent variables were eliminated, because they did not express sufficient consistency in relation to the model proposed, or did not reveal a high coefficient of correlation with other items measuring the same construct. The estimate of the internal consistency of all the scales selected respected a cut off loading point of $>0.70$, after the exploratory factor analysis was concluded ${ }^{40}$. The second part of this study focuses on the development of the confirmatory model. Another 180 companies that are Esprinet customers, with characteristics similar to those selected in the sample used for the explorative analysis, were invited to respond ${ }^{41}$. The response rate was $62 \%$, confirming once again the high response rate and the interest in the research on the part of the top managers invited to complete the questionnaire. In the end, 112 questionnaires were available for analysis. The confirmatory model therefore allowed the hypothesis to be tested (the choice of the test model is perfectly 
consistent with the indications of management literature on the subject - Gerbin \& Anderson, 1988). The decision to maintain unaltered the structure of the selected latent variables was also justified by the evidence of the fit ratios, which produced more than satisfactory values ${ }^{42}$. The results obtained showed the good internal robustness of every dimension identified in the model; similarly, the composite reliability (a measurement generated by LISREL, similar to Cronbach's Alpha) also gave generally high values. And finally, the variance extracted for each dimension was generally above 0.60 , indicating that the variance was common to the indicators of each dimension ${ }^{43}$. The hypothesis $\mathrm{H} 1$ indicates that knowledge of the shopping script generally has a positive impact on the customer's resistance to change. The confirmatory model developed clearly underlines this close correlation (the coefficient $\phi$ varies within a range of 0.21 to 0.67 , depending on the switching cost referred to). In particular, knowledge of the shopping script is more closely linked to lost performance costs $(\phi=0.67)$ and to learning costs $(\phi=0.54)^{44}$. The test helps us to understand the opportunities for online companies in the B2B field, offered by the development of a shopping script in the customer: the performance obtained thanks to an effective online customer service, and the customer's reluctance to abandon consolidated procedures to purchase from another website, with the risk of longer purchasing times, are a guarantee of loyalty that is not easily eroded. Similarly, hypothesis $\mathrm{H} 2$ is an interesting consequence of the construct previously identified. In a B2B market, the cost of the cognitive effort necessary to learn how a new website functions, combined with the perception of satisfaction in the use of the customer service facilities offered by a website, which can minimise purchasing times, make the professional operator willing to pay a premium price in order to maintain his shopping script and to continue to purchase from his habitual supplier. The cost of the coefficient $\phi$ in the confirmatory model developed reveals a strong link between the customer's wish to pay the premium price and his consolidated knowledge of a shopping script $(\phi=0.82)$. The conclusion is extremely important; first of all from the company's perspective, as it has a chance to increase its margin, and simultaneously to consolidate the loyalty of its consumers, exploiting its own customer service. And it obviously has interesting elements for research, particularly if we think that this is has emerged in a market with typically high rates of disloyalty. As we mentioned earlier, the purpose of this study was to introduce two innovations to the managerial literature: a) is an attempt to analyse the purchasing experience from the customer's perspective in a global market (digital economy); b) is an initial study of a B2B market. On digital global markets, because of the low cost of the search for alternative suppliers, the sale of a physical asset is usually accompanied by a jumble of services that make the purchase more inviting and boost the fidelity of the relationship. On B2B markets, the customer is a professional operator in the sector: his purchases therefore reflect the technical aspects of the product, the price, but above all the services that the website offers with the product (in the case of an online purchase). B2B has peculiar structural connotations: first of all regarding customers' demographic characteristics (professional operators in the sector compared to end users), their purchasing capacity (in bulk rather than retail), their contractual power (attributable directly to greater negotiating power linked to the type of purchases, regarding the variables 'temporal continuity' and 'purchasing volumes'), the determinants of their loyalty (compared to B2B customers, B2B operators tend to be more rational in their purchases). As a result, the empirical analysis reveals that 
in a digital economy, and particularly in the B2B sector, it is vital for companies that aspire to maximise their customers' spontaneous resistance to change, to induce the customer to create a shopping script. The presence of a shopping script gives to the individual a sense of the order, organisation and structure of the stimuli from the environment, simplifying the management of cognitive activities. The benefits inherent in the script would justify a consistent reluctance on the part of the individuals to modify the purchasing patterns adopted. Moreover, the tendency of consumers on B2B markets to maintain their purchasing patterns unchanged, thus speeding up the purchasing process (a critical factor for a company or for professional operators in general), and not to re-examine the conditions of the consolidated pattern, are cognitive manifestations of spontaneous resistance to change in the patterns acquired. Recent studies conducted into customer-website interaction $^{45}$ (Smith \& Brynjolfsson, 2001; Zauberman, 2002; Johnson, Bellman \& Lohse, 2003; Del Giudice \& Polski, 2004; Del Giudice, 2004) confirm that knowledge of a shopping script on the Internet positively influences the individual's capacity to conclude his purchases rapidly, the general level of control perceived by the user and, as a consequence, the individiual's overall level of satisfaction.

\section{Bibliography}

Alba J., Lynch J., Weitz B., Janiszewski C., Lutz R., Sawyer A., Interactive Home Shopping, Consumer, Retailer and Manufacturer Incentives to Participate in Electronic Marketplaces, Journal of Marketing, vol.61, n. 3, 1997, pp. 38-53.

http://dx.doi.org/10.2307/1251788

Brondoni S.M., Global Markets and Market-Space Competition, Symphonya. Emerging Issues in Management (symphonya.unimib.it), n. 1, 2002. http://dx.doi.org/10.4468/2002.1.03brondoni

Castaldo S., Botti S., La dimensione emozionale dello shopping: una ricerca esplorativa sul ruolo del punto vendita, Economia \& Management, n. 1, 1999, pp. 17-37.

Costabile M., Il capitale relazionale: gestione delle relazioni e della customer loyalty, McGraw Hill, Milan, 2001.

Del Giudice M., Turning Web Surfers into Loyal Customers: cognitive Lock-In Through Interface Design And Website Usability, Gao Y. (ed.), Web Systems Design and Online Consumer Behavior, Idea Publishers, NY, Hershey, PA, 2004.

http://dx.doi.org/10.4018/978-1-59140-327-2.ch016

Dell'Anno D., Van der Sijde P., Del Giudice M., A Script-Based Approach to Spin Off: Some First Issues on Innovative Pathways of Knowledge Transfer and Academic Knowledge's Reproducibility, $12^{\text {th }}$ HTSF Conference, $25^{\text {th }}$ May, Twente University Press, Twente, The Netherlands, 2004.

Gioia D.A., Poole P.P., Scripts in Organizational Behaviour, Academy of Management Review, vol. 10, n. 3, 1984.

http://dx.doi.org/10.2307/258285

Golinelli G.M., L'approccio sistemico al governo dell'impresa, Vol. I, Cedam, Padua, 2000.

Johnson E.J., Bellman S., Lohse G.L., Cognitive Lock-in and the Power Law of Practice, Journal of Marketing, vol. 67, 2003, pp. 62-75.

http://dx.doi.org/10.1509/jmkg.67.2.62.18615

Jones M.A., Mothersbaugh D.L., Beatty S.E., Why Customers Stay: Measuring the Underlying Dimensions of Services Switching Costs and Managing Their Differential Strategic Outcomes, Journal of Business Research, vol. 55, 2002. http://dx.doi.org/10.1016/S0148-2963(00)00168-5 
Leigh T., Rethans A.. Experiences with Script Elicitations Within Consumer Decision Making Contexts, R. Bagozzi, A. Tybout (eds.), Advances in Consumer Research, vol. 10, Proceedings of the $13^{\text {th }}$ Annual Conference, Association of Consumer Research, Ann Arbor (MI), 1983, pp. 667672.

Maggioni V., Del Giudice M., Relazioni sub-sistemiche, diffusione d'imprenditorialità interna e processi di gemmazione: una verifica empirica, Brondoni S.M. (ed.), Il sistema delle risorse immateriali d'impresa: cultura d'impresa, sistema informativo e patrimonio di marca, Giappichelli, Turin, 2004.

Meng Leong S., Bush P., Roedder J.D., Knowledge Base and Salesperson Effectiveness: a Script Theoretic Analysis, Journal of Marketing Research, vol. 26, 1989, pp. 164-178. http://dx.doi.org/10.2307/3172603

Shapiro C., Varian H.R., Informatiom Rules. A Strategic Guide to the Network Economy, Harvard Business School Press, Boston, 1999.

Schurr P., Four Script Studies: What We Have Learned, Lutz R. (ed.), Advances for Consumer Research, vol. 13, Association for Consumer Research, Provo, UT, 1986, pp. 498-503.

Stoltman J., Tapp S., Lapidus R., An Examination of Shopping Scripts, Srull T. (ed.), Advances for Consumer Research, vol. 16, Association for Consumer Research, Provo, UT, 1989, pp. 384-391.

Tansik D., Smith W., Dimension of Job Scripting in Services Organization, International Journal of Service Industry Management, vol. 2, n. 1, 1991, pp. 35-49.

Woofford J., An Examination of the Cognitive Process Used to Handle Employee Job Problems, Academy of Management Journal, vol. 37, n. 1, 1994, pp. 180-192.

\section{Notes}

${ }^{1}$ Cf. Costabile M., Il capitale relazionale: gestione delle relazioni e della customer loyalty, McGraw-Hill, Milan, 2001

${ }^{2}$ In the literature there are numerous contributions that analyse the intensification of competitive dynamics in a situation of over-supply (S > D) (Brondoni Silvio M., Global Markets and MarketSpace Competition, Symphonya. Emerging Issues in Management (symphonya.unimib.it), n. 1, 2002; Brondoni Silvio M., Overture de 'Corporate Culture and Market Complexity, Symphonya. Emerging Issues in Management (symphonya.unimib.it) n. 2, 2002; Corniani Margherita, Sistema informativo aziendale e dinamiche competitive, Giappichelli, Turin, 2000; Corniani Margherita, Segmentazione e aggregazione della domanda aziendale, Giappichelli, Turin, 2004; Lambin JeanJacques, Marketing Strategico ed Operativo, McGraw-Hill, 2004).

${ }^{3}$ Gnecchi Flavio, Brand Portfolio Reengineering. The Gruppo Coin Case, Symphonya. Emerging Issues in Management (symphonya.unimib.it), n. 1, 2001; Wind J. \& Mahajan V. (eds.), Digital Marketing, Wiley, New York, 2001. Regarding the issues of relational complexity as a function of the knowledge transfer processes, cf. Maggioni V. \& Del Giudice M., Relazioni sub-sistemiche, diffusione d'imprenditorialità interna e processi di gemmazione: una verifica empirica, Brondoni S.M. (ed.) Il sistema delle risorse immateriali d'impresa: cultura d'impresa, sistema informativo e patrimonio di marca, Giappichelli, Turin, 2004

${ }^{4}$ Cf. Day G.S. \& Wensley R. (1983). Marketing Theory with a Strategic Orientation, Journal of Marketing, n. 4, pp.78-89; Grönroos C. (1994a). Quo Vadis Marketing? Toward a Relationship Marketing Approach, Journal of Marketing Management, n. 10, pp. 347-360. We refer, particularly, to Maggioni V. (2000). Apprendere dalle strategie relazionali delle imprese: modelli ed esperienze per le meta-organizzazioni, Sinergie, vol. 52.

${ }^{5}$ For a broad examination of the structure of the global markets and the digital economy, see Varian H. (2000), Markets for Information Goods, in Monetary Policy in a World of KnowlegeBased Growth, Quality Change, and Uncertain Measurement, Conference proceedings, available at http://www.sims.berkeley.edu/ hal/Papers/japan/japan.pdf (accessed September 2004).

${ }^{6}$ Cf. Maggioni V. (2000), cit.; Golinelli G.M. (2000). L'approccio sistemico al governo dell'impresa, vol. I, Cedam, Padova; Sciarelli S. (2002). Economia e Gestione dell'Impresa, Cedam, Padua. 
${ }^{7}$ Cf. Woofford J. (1994). An examination of the cognitive process used to handle employee job problems, Academy of Management Journal, vol. 37, n. 1, pp. 180-192.

${ }^{8}$ In general terms, marketing and organisational behaviour were the fields of study that have most often exploited concepts borrowed from cognitive psychology research. One of the first works on the subject of research into organisational behaviour is the article by Gioia \& Poole (1984), which examines the repetitiveness of certain activities of the organisation and the development of stereotyped actions that make the concept of the script easily applicable to the study of the organisation's cognitive and behavioural relations. The concept of learning in the organisation was analysed further in a later work by Gioia \& Manz (1985): anyone who is hired by a company must learn a behavioural script that is transferred to him by those who already work for that company (like the case of the training and preparation of employees). One of the studies that have inspired this work most was certainly Woofford's decisive contribution (1994): knowledge of organisational procedures, the cognitive processes that underpin actions, and decision-making processes are memorised by the individual in the form of scripts. And finally, the study by Tansik and Smith (1991) is certainly of interest: repeated actions allow the script to become habitual behaviour. When the script is performed automatically, the individual's cognitive effort is reduced. Cf. the latest studies of the aptitude of scripts to transfer the company's cognitive map through spin-off operations (cf. Dell'Anno D. \& Del Giudice M. (2002), The spin off model: a simultaneous way to knowledge transfer and entrepreneurship stimulation, $7^{\text {th }}$ World Congress on Total Quality Management, CUEIM; Dell'Anno D., Van der Sijde P. \& Del Giudice M. (2004), A script-based approach to spin off: some first issues on innovative pathways of knowledge transfer and academic knowledge's reproducibility, $12^{\text {th }}$ HTSF Conference, $25^{\text {th }}$ May, Twente University Press, Twente, The Netherlands; Maggioni \& Del Giudice (2004), cit.).

${ }^{9}$ In this regard refer to Shurr P. (1986). Four script studies: what we have learned, in Lutz R. (ed.), Advances for consumer research, vol. 13, Association for Consumer Research, Provo (UT), pp. 498-503; Leigh T. \& McGraw P. (1989). Mapping the procedural knowledge of industrial sales personnel: a script-theoretic investigation, Journal of Marketing, vol. 53, January, pp. 16-34; Meng Leong S., Bush P. \& Roedder J. D. (1989). Knowledge base and salesperson effectiveness: a script theoretic analysis, Journal of Marketing Research, vol. 26, May, pp. 164-178.

${ }^{10}$ Cf. Leigh T. \& Rethans A. (1983). Experiences with script elicitations within consumer decision making contexts, in R. Bagozzi \& A. Tybout (eds.), Advances in consumer research, vol. 10, Proceedings of the $13^{\text {th }}$ Annual Conference, Association of Consumer research, Ann Arbor (MI), pp. 667-672.

${ }^{11}$ For a critical review of the issue, we refer you also to Bozinoff L. \& Roth V. (1983). Recognition memory for script activities: an energy conservation application, in Bagozzi R. \& Tybout A. (eds.), Advances in Consumer Research, vol. 10, Proceedings of the $13^{\text {th }}$ Annual Conference, Association for Consumer Research, Ann Arbor (MI), pp. 655-660.

${ }^{12}$ The theory of limited rationality emerged as a response to the theories of choice which consider the individual as a perfectly rational decision-maker, capable of precisely evaluating the gamut of available alternatives when he makes his choice, and the consequences that may derive from each choice. Observation of the fact that the decision is not made in conditions of perfect information about the available alternatives and the consequences that can derive from each alternative, but rather in conditions of uncertainty regarding the future consequences (in other words the individual, in the role of decision-maker, would only be aware of the probability of the various possible results in relation to the action taken).

${ }^{13}$ Cf. Nisbett R. \& Ross. L. (1980). Human inference: strategies and shortcomings of social judgment. Italian contributions on the issue include Grandori A. (1995). L'organizzazione delle attività economiche, Il Mulino, Bologna.

${ }^{14}$ Cf. Sorrentino M. (1996), L'imprenditorialità interna per l'innovazione, Cedam, Padua.

${ }^{15}$ Cf. Gremler D. (1995). The effect of satisfaction, switching costs and interpersonal bonds on service loyalty, unpublished doctoral dissertation, Arizona State University; Jones M.A., Mothersbaugh D.L. \& Beatty S.E. (2002). Why Customers stay: measuring the underlying dimensions of services switching costs and managing their differential strategic outcomes, Journal of Business Research, 55.

${ }^{16}$ See Jones et al. (2002), cit., pp. 442-443. 
${ }^{17}$ For the type of cost under examination see also Betty et al., 1996 and Heskett et al., 1990.

${ }^{18}$ Cf. Jones et al. (2002), cit., p. 443.

${ }^{19}$ In this regard, the authors write that 'Pre-switching search and evaluation costs represent consumer perceptions of the time and effort involved in seeking out information about available alternatives and evaluating their viability prior to switching' (Jones et al., 2002, p. 443). Research costs are costs associated to the search for and evaluation of a new supplier. Empirical research projects designed to estimate the relationship between research costs and the customer's purchasing behaviour are still very limited today. Lee \& Cunningham (1994) are among a small number of authors who have empirically demonstrated the existence of a positive relationship between the levels of perceived switching costs and the customer's loyalty to the company (cf. Lee C. \& Cunningham L. (1994). Assessing service quality as an effective management tool: the case of the airline industry, Journal of Marketing Theory and Practice, vol. 2, no. 2, pp. 79-96).

${ }^{20}$ The authors write that 'Consumer perceptions of the time and effort needed to acquire and adapt to these new procedures and routines are referred to as post-switching behavioral and cognitive costs' (Jones et al. (2002), cit., p. 443).

${ }^{21}$ The study by Jones et al. (2002, op. cit., p. 443) describes these costs as the 'Perception of the time, effort and expense of relaying needs and information to provider subsequent to switching'.

${ }^{22}$ Cf. Krumske W. (1987). Marketing strategies for pricing services: an application in the deregulated financial service industry, unpublished doctoral dissertation, University of Illinois at Urbana-Champaign.

${ }^{23}$ Empirical research on the influence exerted by learning costs on customer loyalty is still limited (cf. Soellner A. (1994). Commitment in exchange relationships: the role of switching costs in building and sustaining competitive advantages, in Sheth J. \& Parvatiyar A. (eds.), Relationship marketing: theory, methods and applications, Emory University, Atlanta). Gremler (1995) is one of the few authors to include the concept of switching costs among the antecedents of customer loyalty (cf. Gremler D. (1995), op. cit.)

${ }^{24}$ This study and the following empirical analysis concentrate on a global B2B market, in which the customer-company plays a leading role.

${ }^{25}$ For empirical evidence in a traditional (off line) market we refer you to Castaldo S. \& Botti S. (1999). La dimensione emozionale dello shopping: una ricerca esplorativa sul ruolo del punto vendita, Economia \& Management, 1, pp. 17-37.

${ }^{26}$ Cf. Abelson R. (1976). 'Script processing in attitude formation and decision making', in J.S. Carrol and J.W. Payne (eds.), Cognition and social behavior, pp. 33-45, Erlbaum, Hillsdale, NJ, p. 45.

${ }^{27}$ Switching costs have been seen as an exponent of loyalty that is essentially behavioural and inertial but not cognitive (cf. Shapiro C. \& Varian H.R. (1999). Information Rules. A strategic guide to the network economy, Harvard Business School Press, Boston. This conception lies behind the development of lock-in strategies. This study, on the other hand, tries to reverse this viewpoint, starting from the satisfaction in the purchasing experience that can be found in the acquisition of a script that it would be too expensive to lose.

${ }^{28}$ Cf. Shapiro C. \& Varian H.R. (1999), op. cit. We also refer you to the recent work by Srinivasan S.S., Anderson R. \& Ponnavolu K. (2002). Customer Loyalty in e-commerce: an Exploration of its Antecedents and Consequences, Journal of Retailing, 78, pp. 41-50.

${ }^{29}$ Cf. Maggioni V. (1983). Il sistema informativo aziendale, Liguori, Naples

${ }^{30}$ Cf. Alba J., Lynch J., Weitz B., Janiszewski C., Lutz R., \& Sawyer A. (1997). Interactive Home Shopping, Consumer, Retailer and Manufacturer Incentives to Participate in Electronic Marketplaces, Journal of Marketing (61:3). pp. 38-53

${ }^{31}$ Cf. Shostak L. (1977). Breaking Free from Product Marketing, Journal of Marketing, vol. 41, April, pp. 32-34

${ }^{32}$ Cf. Bergen M., Dutta S. \& Shugan S. (1996). Branded Variants: A Retail Perspective, Journal of Marketing Research, 33, February, pp. 9-19

${ }^{33}$ Cf. Alba et al. (1997), cit. 
${ }^{34}$ The analysis was conducted using SPSS 11.0 and LISREL 8.0 software. The sample was split into an exploratory data set of 100 companies and a confirmatory data set of 180 companies, to test the research hypothesis (producing a total of 179 completed questionnaires). However, the research regarded another thirty companies, which were involved in the in-depth interview and the pre-test. I must thank all the managers of these companies for their willingness to answer the questionnaire and to provide information that is very useful for this study.

35 Cf. Glaser B. \& Strauss A. (1967). The discovery of grounded theory. Aldine, Chicago; Eisenhardt K.M. (1989). Building theories from case study research, Academy of Management Review, vol. 14, n. 4, pp. 532-550.

${ }^{36}$ In order to define the scales and the items we followed the indications given in literature by Churchill (1979) and Gerbin \& Anderson (1988) (cf. Churchill G.A. Jr (1979). A paradigm for developing better measures of marketing constructs, Journal of Marketing Research, 16, February, pp. 64-73; Gerbing, D.W. \& Anderson, J.C. (1988). An updated paradigm for scale development incorporating unidimensionality and its assessment, Journal of Marketing Research, 25, May, pp. 186-192)

${ }^{37}$ To these constructs, we must also add the willingness to pay more, measured by adapting scale items present in literature (cf. Zeithaml V. A., L. L. Berry, \& A. Parasuraman (1996). The behavioral consequences of service quality, Journal of Marketing, vol. 60, April, pp. 31-46).

${ }^{38}$ We should point out that the questionnaire was pre-tested on 15 randomly selected companies, before being definitively used to collect the data (testing it on the exploratory data set). The interviewees generally stated that they were able to answer the questions posed without difficulty. However, certain explanations were added to elements judged too generic and the quality of the page layout was improved. The results of the pre-test suggested improving the language of certain statements made in the questionnaire, as well as the quality of the graphics. The personal data were also considerably reduced in order to limit the interviewee's perception of the length of the questionnaire.

${ }^{39}$ Following the methodology outlined by Pettigrew (cf. Pettigrew A. (1990). Longitudinal field research on change: theory and practise, Organization Science, 3, pp. 267-292), the target company was chosen on the basis of its visibility on the market, confirmed by a number of structural indices that are accepted in literature (stock market listing, market share, turnover, number of customers, number of employees).

${ }^{40}$ Cf. Nunnally J.C. \& Bernstein I.H. (1994). Psychometric theory, (3 ${ }^{\text {rd }}$ ed.), McGraw-Hill, New York, NJ.

${ }^{41}$ The sample represents the confirmatory data set.

${ }^{42}$ Although $\chi^{2}$ has given statistically high values $\left(\chi^{2}=32.87\right.$, $\left.\mathrm{df}=111, \mathrm{P}<.01\right)$, other fit indices have confirmed the acceptability of the model (Tucker Lewis Index $=0.81$; Comparative Fit Index = 0.94; cf. Bollen K.A. (1989). Structural equations with latent variables, Wiley, New York). It is a known fact that $\chi^{2}$ is conditioned by the size of the sample chosen.

${ }^{43}$ Cf. Fornell C.R. \& Lacker D.F. (1981). Two structural equation models with unobservable variables and measurement error, Journal of Marketing Research, 18, pp. 39-50. In this study, for the purposes of simplicity, we will omit the values for the $\chi^{2}$ difference test, which all gave fully satisfactory values.

${ }^{44}$ One reflection of this validation is given by the test of the subsequent hypothesis in which of all the switching costs, the cost of lost performance $(\phi=0.74)$ and learning costs $(\phi=0.67)$ revealed the greater correlation with the willingness to pay more.

${ }^{45}$ Cf. Smith M.D. \& Brynjolfsson (2001). Consumer decision-making at an internet shopbot: brand still matters, Journal of Industrial Economics, vol. 49, n. 4, pp. 541-558; Zauberman G. (2002), Lock-in over time: time preferences, prediction accuracy, and the information cost structure, in Broniarczyk S. M. \& Nakamoto K. (eds.), Advances in Consumer Research, vol. 29, pp. 9-10; Johnson E.J., Bellman S. \& Lohse G.L. (2003). Cognitive lock-in and the power law of practice, Journal of Marketing, vol. 67, pp. 62-75. We also refer you to the recent work by Del Giudice M. \& Polski M. (2003). Having to be loyal or wanting to be loyal: the role of the website on customer churn and retention, International Business Information Management Association, NY and Del Giudice M. (2004). Turning Web Surfers into Loyal Customers: cognitive lock-in through interface 
design and website usability, in Gao Y. (ed.), Web Systems Design and Online Consumer Behavior, Idea Publishers, NY, Hershey, PA. 